\title{
Some considerations about the use of lime-cement mortars for building conservation purposes in Portugal: A reprehensible option or a lesser evil?
}

\author{
F. Pacheco-Torgal ${ }^{\text {b,* }}$, J. Faria ${ }^{\mathrm{a}}$, S. Jalali ${ }^{\mathrm{b}}$ \\ a Dep. of Civil Engineering, University of Minho, Portugal \\ ${ }^{\mathrm{b}} \mathrm{C}$-TAC Research Unit, University of Minho, Portugal
}

\section{A R T I C L E I N F O}

\section{Article history:}

Received 3 September 2011

Received in revised form 4 November 2011

Accepted 2 December 2011

\section{Keywords:}

Lime-cement

Lime-pozzolans

Portland cement

Conservation mortars

\begin{abstract}
A B S T R A C T
Some investigations about conservation actions in historical buildings points out that lime-cement mortars should be avoided and lime-pozzolan mortars should be use instead. Nevertheless this type of mortar is still under investigation and the absolute rejection of the use of Portland cement even with just a minimum amount appears to be a dogmatic position that is not fully grounded in scientific terms. Besides the use of lime-pozzolan mortars requires skilled craftsmanship and at least in the case of the majority of Portuguese construction enterprises operating in the field of building conservation these conditions are not assured. These facts can influence the decision about the mortars choice for conservation purposes, since in certain circumstances it may be preferable to apply lime-cement mortars instead of an incorrect application of lime-pozzolan mortars.
\end{abstract}

(C) 2011 Elsevier Ltd. All rights reserved.

\section{Introduction}

The preservation of Portuguese architectural heritage is a national imperative due to the importance which it assumes in the context of the identity of a country with eight centuries of history and as a necessary condition for the preservation of this memory, or even for economic reasons related to the impact of Tourism on Portugal's economy. Only recently has the high level degradation of the architectural heritage has caught the media attention, with the suggestive title "A third part of Portuguese UNESCO architectural heritage at risk of collapse" [1]. Regarding the conservation mortars, Portland cement appearance came to dethrone air lime mortars because the new binder had a higher mechanical strength and a low setting time allowing for work completion in relatively short period. More recently it has been observed that Portland cement is not the magic formula that it was initially thought to be and it is responsible for several problems in the building rehabilitation area, where frequent pathologies are associated with its use. It is chemically incompatible with lime based mortars; it is responsible for the introduction of soluble salts; it has a low permeability and a high modulus of elasticity that is unable to accommodate for masonry deformations. Also, the Venice Charter, which gathers conservation principles no longer sees Portland cement as a preferred material, as it was been done under the Athens Charter, but accepts materials and modern techniques whose effectiveness is scientifically proven [2]. Some authors [3] point out that the formulation of lime-cement mortars "not only the advantages of them come together but also their disadvantages".

\footnotetext{
* Corresponding author. Tel.: +351253 510200; fax: +351253510213.

E-mail address: torgal@civil.uminho.pt (F. Pacheco-Torgal).
}

However, a total rejection of mortars that can contain only minimal amounts of Portland cement is not supported by scientific evidence, but appears to be a dogmatic position that is not advisable. Although lime based mortars have regained an increasing interest in the conservation field they remain a slow hardening binder. This poses serious obstacles in the implementation of mortars that have hardening times exceeding 1 year [4]. This can be overcome by the use of formulations containing pozzolanic additions. Besides, the authors share the position of Jornet et al. [5] about the fact that "the reintroduction of lime based mortars has been, and still is, accompanied by disappointing failures". Nevertheless, reducing the whole problem to a simple accounting of the advantages and disadvantages between lime-cement or lime-pozzolan mortars is a very simplistic analysis, partly because in the conservation of certain monuments some original materials like aerial mortars must be used. On the other hand because it should broaden the discussion to a wider scope that may consider other factors intrinsic to the construction market, such as the level of training of technicians and workers. Whether that can or cannot influence this issue, and to what extent this may happens. This paper deals with conservation mortars by reviewing previously published work. The use of lime-cement mortars is analyzed. Considerations about the existence of Portuguese skilled craftsmanship are made.

\section{Conservation mortars}

\subsection{Previous considerations}

The conservation of old renders has a high level of complexity that is inconsistent with amateur approaches from design to 
execution. This type of work should be preceded by an analysis of the depth of degradation and an analysis of the historical or artistic value of the property to be rehabilitated. In case of buildings with historical relevance or artistic value, the first option should always be to undergo conservation of old renders through maintenance operations. If by any reason that is not possible a consolidation operation maybe needed. If the level of degradation is very high, partial or total replacement operations may be advisable, although this is usually the last option that should be taken into account [6,7]. Any restoration work must be preceded by an inspection of the materials to be restored, because ancient masonry walls are very irregular and in most cases renders have high heterogeneity thicknesses. Beyond what may be the implicit historical value in the use of original materials and techniques, there is the significant issue of the compatibility between substrate and conservation materials. Materials with different mechanical behavior and different physical-chemical characteristics, will lead sooner or later to situations of poor performance. Materials with different permeability levels, different modulus of elasticity, different adhesion levels or even with different levels of water absorption can hardly constitute a good conservation solution, because sooner or later they end up being the cause of pathologies. Some authors have analyzed the minimum performance characteristics of conservation mortars (Tables 1 and 2) [8,9]. As important as the materials used in rehabilitation works is their correct application [10]. Therefore if a correct conservation work requires the use of appropriate materials, it also requires a good mason for a good execution [11]. Render mortars must be executed in several layers, with decreasing mechanical strength [12]. Recent investigations describe some techniques and recommendations that must be taken under consideration in the execution of lime renders for old buildings [13]:

- Clearing the substrate from impurities and filling depressions.

- Using just the amount of water necessary to assure the minimum consistency.

- Using mechanical mixing supplemented by hand mixing.

- Hard projection of mortar followed by mason trowel compression.

- Protecting renders from sun exposure to prevent fast drying.

- Protecting renders from rain exposure to prevent carbonation inhibition.
- Applying several thin layers leaving enough time between them for the carbonation of the previous layer (at least a week).

Regarding to the last recommendation one must consider that specific circumstances may lead to carbonation times of several months (see Table 3 and Fig. 1) [4]. Even the use of hydraulic lime based mortars does not always guarantee successful results. Penas et al. [14] studied several hydraulic lime mortars, yielding a high variation of results that in some cases do not meet the minimum mechanical requirements, which is due to the very different amounts of limestone and clay used in the manufacture process of this lime. This scenario thus allows a obvious inference, that this subject has an inherent complexity that makes it essential for the use of technicians and workers with a high level of expertise.

\subsection{Lime-pozzolan mortars}

The use of pozzolanic materials in construction dates back to thousands years ago. Roy and Langton [15] suggests that calcined clays mix with slaked lime (calcium hydroxide) were the first hydraulic binder made by men. Malinowsky [16] reports ancient constructions from 7000 BC in the Galilei area (Israel) using this type of binder. The eruption of Thera in $1500 \mathrm{BC}$, which destroyed part of Santorini Island was responsible for the appearance of large amounts of ashes used by the Greeks to make mortars that reveal having hydraulic properties. However, the Romans already knew that artificial pozzolans (calcined clay) were needed to produce mortars with a high performance, so their use was not conditioned by the availability of natural pozzolans [17]. The Roman mortars used for the Hadriańs wall in Britain were made of crushed ceramic material mixed with lime binder [18]. Crushed ceramics seem also to be preferred from early Hellenistic to early Byzantine times in mortars related to water-bearing constructions and to protect the inside of walls from moisture, typically in baths, canals and aqueducts $[19,20]$. Several of the monuments that survived to the twenty first century like the triumphal arches of the Emperors Claudius and Trajan in Ostia or the bridges of Fabricus, Aemilius, Elius e Milvius shows the durability of lime-pozzolan based mortars [21,22]. Fig. 2 [23] shows how lime-pozzolan were lost even before Middle Ages and how the appearance of Portland cement "dictated" the end of the use of lime based mortars because the

Table 1

General mechanical requirements concerning some characteristics for rendering mortars of ancient buildings [8,9].

\begin{tabular}{|c|c|c|c|c|c|c|c|c|}
\hline \multirow[t]{2}{*}{ Type of render } & \multicolumn{3}{|c|}{ Mechanical characteristics (MPa) } & \multirow[t]{2}{*}{ Adhesion strength (MPa) } & \multicolumn{4}{|c|}{ Restrained shrinkage behavior } \\
\hline & Rt & $\mathrm{Rc}$ & $E$ & & Fr $\max (\mathrm{N})$ & $G(\mathrm{~N} \mathrm{~mm})$ & CSAF & CREF (mm) \\
\hline Exterior render & -0.7 & -2.5 & -5000 & -0.3 & $<70$ & $>40$ & $>1.5$ & $>0.7$ \\
\hline Interior render & -0.7 & -2.5 & -5000 & & & & & \\
\hline Reporting mortar & -0.8 & -3 & -6000 & -0.5 & & & & \\
\hline
\end{tabular}

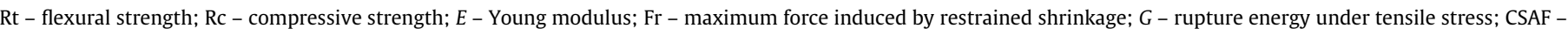
security coefficient related to the opening of the first crack, CREF - resistance coefficient to cracking: CREF $=G / F r$.

Table 2

General water performance requirements concerning some characteristics for rendering mortars of ancient buildings [8,9].

\begin{tabular}{|c|c|c|c|c|c|}
\hline \multirow[t]{3}{*}{ Type of render } & \multicolumn{5}{|c|}{ Water performance } \\
\hline & \multicolumn{2}{|c|}{ Current tests } & \multicolumn{3}{|c|}{ Moisturemeter testes } \\
\hline & $S_{d}(\mathrm{~m})$ & $C\left(\mathrm{~kg} / \mathrm{m}^{2} \mathrm{~h}^{0.5}\right)\left(\mathrm{kg} / \mathrm{m}^{2} \min ^{0.5}\right)$ & $M(\mathrm{~h})$ & $S(\mathrm{~h})$ & $H(\mathrm{~m} v \mathrm{~h})$ \\
\hline Exterior render & $<0.08$ & $\begin{array}{l}<12 ;>8 \\
<1.5 ;>1\end{array}$ & $>0.1$ & $<120$ & $<16,000$ \\
\hline Interior render & $<0.1$ & - & - & & - \\
\hline Reporting mortar & $<0.1$ & $\begin{array}{l}<12 ;>8 \\
<1.5 ;>1\end{array}$ & $>0.1$ & & $<16,000$ \\
\hline
\end{tabular}

$S_{d}$ - thickness of air layer with equivalent diffusion of water vapor; $C$ - capillarity coefficient; $M$ - wetting retardness; $S$ - moisture period; $H$ - wetting intensity. 
Table 3

Minimum time needed for the application of a lime mortar rendering inside a church in Portugal [4].

\begin{tabular}{|c|c|c|c|c|c|}
\hline Spring & Summ & Autumn & Winter & Spring & Summer \\
\hline Layer 1 & & & & & \\
\hline & Layer 2 & & & & \\
\hline & & & Layer 3 & & \\
\hline
\end{tabular}
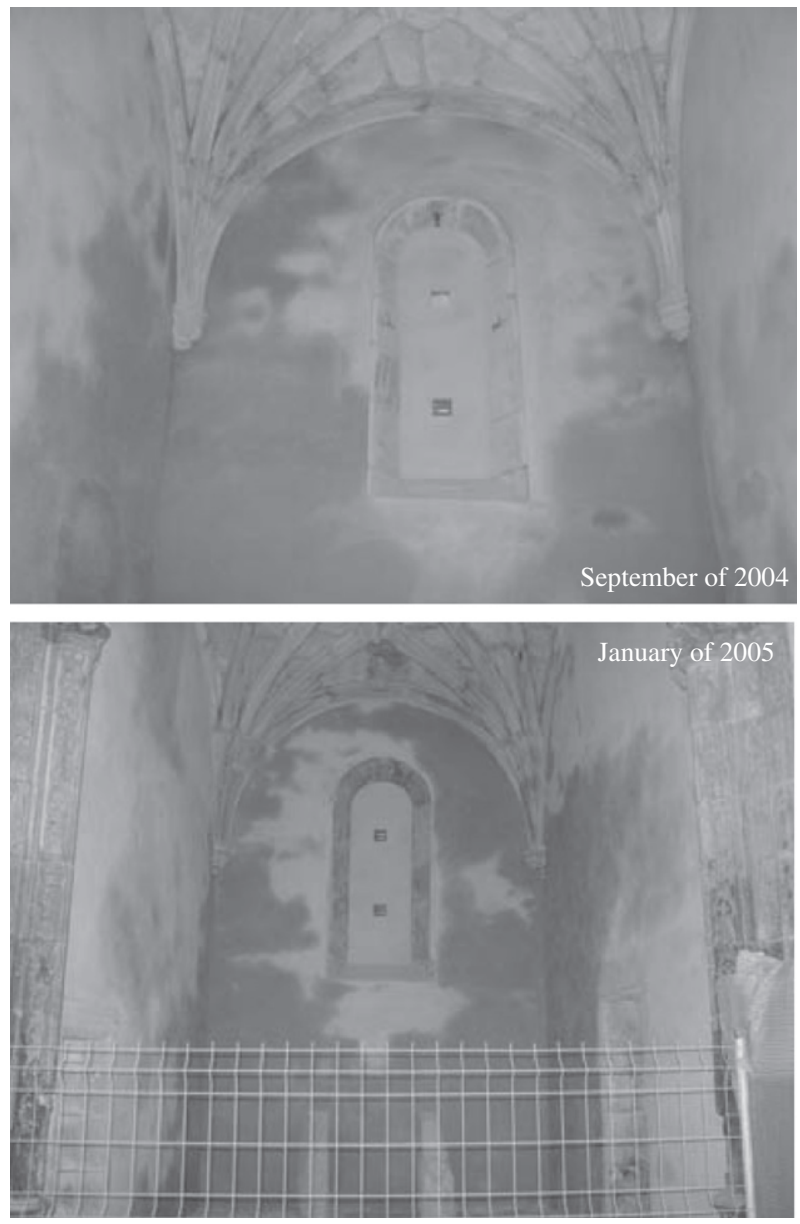

Fig. 1. Drying of a lime-based rendering inside a church in Portugal [4]

former were not as strong and durable as Portland cement based ones. The pozzolanic reactivity, i.e. the ability of the material to combine with calcium hydroxide, is a complex property dependent on the fact that silica and alumina are not present in a high degree of crystallinity. Generally speaking the reactive aluminosilicate pozzolan will react with the calcium hydroxide to form calcium silicates and aluminates. Despite being known for a long time this is not a sufficient condition to allow them to be used by the construction market, partly because the knowledge we reached is a empirical one and also because the quality requirements of modern construction processes, implies that this knowledge must be scientifically confirmed. This is the reason why in recent years we saw a rinsing in the investigations about these materials $[24,25]$. Besides the numerous amount of pozzolan types that can be used in conservation mortars, widens the variables that should be investigated. Since different aluminosilicate materials have different dehydroxilation degrees [26-29] is not possible to infer the pozzolanic activity of a certain aluminosilicate from another one. Recent investigations about the pozzolanic activity of certain clays showed that its thermal treatment may lead to an agglomeration behavior reducing the specific surface which was found to be the highest for montmorillonite, followed by illite and kaolinite (Table 4) [30]. Furthermore, according to direct test methods (XRD, TGA, Frattini test, the saturated lime test and the Chapelle test) certain aluminosicates exhibit pozzolanic activity with lime but fail to do so with cement and vice versa [31-33]. This helps to explain why some potential pozzolans sometimes show an unexpected weak activity and why different standards related to the pozzolanic activity index generate conflicting results [34,35]. Velosa [36] studied the influence of lime mortars for conservation purposes containing several artificial pozzolans (brick dust, metakaolin, silica fume) and also natural pozzolans from the Portuguese Azores islands. The results obtained by this author confirm the compatibility between lime-pozzolan conservation mortars and stone masonry substrates. They also confirm that these mortars have a high water vapor permeability, present a fast drying rate and have low susceptibility to cracking. More recently other authors [37] studied the use of rice husk ash as pozzolan for lime mortars, noticing that they lead to an increased resistance to soluble salts (sulfates and chlorides), clearly showing the importance of research needs in this field. Recent investigations show that repair mortars of historic buildings with high pozzolan content experience considerably high creep values [38]. Veiga et al. [39] point out there was insufficient knowledge regarding the application conditions for lime-pozzolan mortars, emphasizing that cure conditions may play a crucial role in determining its performance [40]. This reinforces once again the influence of the technical skills or the lack of them in workers, who will execute and in the technicians, who will supervise this type of mortars.

\subsection{Lime-cement mortars}

Hardening of lime-cement mortars happens in a combined action of cement hydration and lime carbonation. Colantuono et al. [41] stated that lime-cement mortars are needed to stop capillary rise of water in masonries. Other authors [42,43] found that some lime-cement mortars (with high sand content) were more appropriate for restoration purposes than mortars with hydraulic lime. These authors reported that the effect of cement on porosity and pore size of the mortars should is crucial since changes in texture can substantially modify key properties of the mortars such as its breathability. Mortars that are more permeable to water vapor than the stones significantly reduce the water transport in the stone pore structure because water evaporates quickly through the mortars pore. Arandigoyen and Alvarez [44,45] shows that lime-cement mortars are preferred to cement based or lime based ones. Sébaïbi et al. [46] shows that a substitution of a small percentage of lime by cement (below $10 \%$ in mass) does not modify the microstructure of the mortar. This is a crucial aspect for mortar performance. Elpida-Chrissy et al. [47] advocate the use of Portland cement in order to ensure a minimum mechanical strength at early ages. According to Cizer et al. [48] lime-cement mortars are preferred for repair mortars because they allow more deformation in the masonries. It is true that Portland cement react with carbonic acid and form alkali carbonate or bicarbonate salts [49] however if Portland cement is used in a small amount this will remain a minor problem. Besides the damage mechanism of salt crystallization is related to the pressure of salts in the pore radius, the smaller the pores the higher the supersaturation [50,51]. This phenomenon is less damaging in a high porosity and high pores medium like lime-cement mortars [52]. It's worth mention that has Groot et al. [53] put it "Completely salt-resistant plasters do not exist". Martinez and Carro [54] analyzed several blended mortars (Table 5) with increasing Portland cement percentage, concluding that although an increase in cement content increases the amount 




Fig. 2. Use of binders during history [23].

Table 4

Effect of calcination on the specific surface of kaolinite, illite and montmorillonite [30].

\begin{tabular}{ll}
\hline Clay & Specific surface $\left(\mathrm{m}^{2} / \mathrm{g}\right)$ \\
\hline Raw kaolinite & 26.1512 \\
Kaolinite $600^{\circ} \mathrm{C}$ & 24.698 \\
Kaolinite $800^{\circ} \mathrm{C}$ & 24.1283 \\
Raw illite & 21.3277 \\
Illite $600^{\circ} \mathrm{C}$ & 18.4316 \\
Illite $800{ }^{\circ} \mathrm{C}$ & 13.3214 \\
Raw montmorillonite & 31.0287 \\
Montmorillonite $600^{\circ} \mathrm{C}$ & 21.386 \\
Montmorillonite $800^{\circ} \mathrm{C}$ & 9.7221 \\
\hline
\end{tabular}

of soluble salts (Fig. 3), this amount does not increase in a proportional manner. Only the mixtures D3 to D6 have a higher amount of soluble salts. The presence of lime influences cement hydration and salts remain in a soluble state except for the mixtures with a high cement percentage up to $80 \%$. The mixtures with a low cement percentage show a low compressive strength and high water vapor permeability (Fig. 4) [54] characteristics appropriate for conservation mortars. Faria et al. $[55,56]$ confirmed that certain limecement mortars allows for an acceptable behavior concerning compressive strength and water vapor permeability. Sepulcre-Aguilar and Hernández-Olivares [57] show that lime-cement mortars have similar phase formation to hydraulic limes with much more moderate strength confirming that they are an interesting alternative for restoration purposes. The mortars containing lime and Portland cement can be formulated in order to meet the requirements for conservation mortars such as high water vapor permeability, low strength and low modulus of elasticity. Veiga et al. [58] have shown that some blended mortars containing Portland cement are able to meet minimum requirements for conservation mortars related to mechanical behavior and water performance (Table 6). Veiga [59] recently stated that "lime-cement mixes can also be acceptable binders" for repair of historic mortars. Especially in mortars for historical buildings close to the sea [60], which are exposed to very harsh conditions with a high content of sodium chloride salts, this helping to demystify some of the alleged demerits of these mortars.

\subsection{Commercial pre-pack mortars for conservation purposes}

Another hypothesis for conservation mortars apart from limepozzolan mortars and lime-cement mortars could be the use of commercially available pre-pack mortars. However, these materials present several disadvantages. They are not cost-efficient and in many cases they present an excessive mechanical performance [61-64], even above the requirements for conservation mortars (Table 7). Besides some commercial mortars use Portland cement and are responsible for a high amount of soluble salts [65]. Last but not the least, the fact that manufacturers do not usually disclose their full composition may lead to compatibility problems with the masonry substrate [64]. Jornet et al. [5] recommend the use of these mortars if skilled craftsmanship and good site practices could not be met in order to produce a lime-mortar of good quality, this can only be understood in the light of the recent lime-cement mortars phobia.

\section{Technicians and workers level of expertise}

A simple comparison between the advantages and disadvantages of lime-cement mortars versus lime-pozzolan mortars, does not allow for an adequate framework of the subject examined in this manuscript. The conditions related to the execution of those mortars and, most important the level of expertise of workers and technicians must also be addressed. In Portugal the majority of workers in the construction industry have a low education level. The majority of them have only 4-6 years of secondary education [66], and their expertise in the construction field was acquired over some decades. This could lead to unsuccessful lime-pozzolan mor-

Table 5

Mortars samples tested: lime and cement content in volume and weight [54]

\begin{tabular}{|c|c|c|c|c|}
\hline Composition & Apparent vol. powder lime:cement & Weight powder lime:cement & Weight (\%) cement content/total binder & Apparent vol. paste lime:cement \\
\hline D1 & $1: 0$ & $1: 0$ & 0 & $1: 0$ \\
\hline D2 & $10: 1$ & $5: 1$ & 17 & $11: 1$ \\
\hline D3 & $4: 1$ & $2: 1$ & 33 & $4.4: 1$ \\
\hline D4 & $2: 1$ & $1: 1$ & 50 & $2.2: 1$ \\
\hline D5 & $1: 1$ & $1: 2$ & 67 & $1: 0.9$ \\
\hline D6 & $1: 2$ & $1: 4$ & 80 & $1: 1.8$ \\
\hline D7 & $1: 5$ & $1: 10$ & 91 & $1: 4.6$ \\
\hline D8 & $0: 1$ & $0: 1$ & 100 & $0: 1$ \\
\hline
\end{tabular}



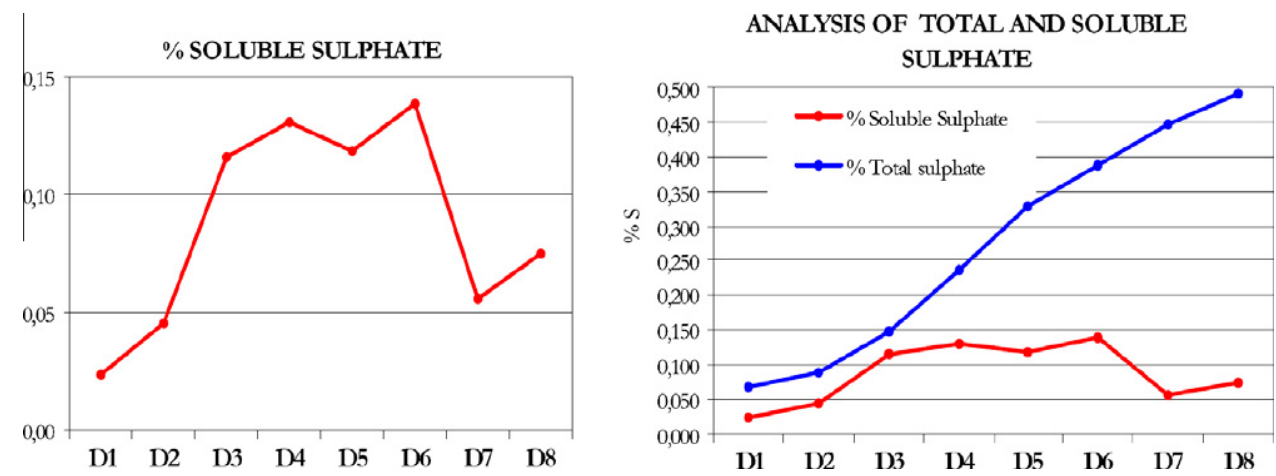

Fig. 3. Interference of lime content in the hydration process of cement compounds blended mortars [54].


Fig. 4. Compressive strength and water-vapor permeability of blended mortars [54].

tars execution. Moreover, the majority of Portuguese construction enterprises are one-person businesses that does not even have technical support that can supervise the implementation of this type of work. Meaning that contrary to happened in the past, nowadays small construction enterprises are not oblige to hire at least an Architect or an Civil Engineer. The most recent Portuguese legislation on this subject ("Portaria" No. 1371/2008 of December 2 related to the equivalence between the work categories and the cost of construction works "permission classes" and "Portaria" No. 16/2004 of 11 January about staff requirements), has evolved because it makes it mandatory that a minimum of technicians must be employed by construction companies, but on the other
Table 7

Compressive strength of several commercial pre-pack conservation mortars [64].

\begin{tabular}{lll}
\hline Company & Product & Rc (MPa) \\
\hline BASF & Albaria SP2 & \\
& $\quad$ Rinzaffo & 3.4 \\
& $\quad$ Tonachino Deumidificante & 3.0 \\
Ciarga & ACH & $3.5-5.0$ \\
& AE & 10.0 \\
Kerakoll & Sanabuild & $>2.5$ \\
Lena & Lena 822 & $1.5-3.5$ \\
Weber & Weber dry sane & 3.0 \\
Secil & Reabilita RBA01 & $1.5-5.0$ \\
Mapei & Mape-Antique MC & $4.0-6.0$ \\
Tradibau & Mape-Antique Rinzaffo & 7.0 \\
\hline
\end{tabular}

hand it is rather permissive because it allows that technicians with only 1 year post-secondary education in Polytechnic Institutions (CET́s) can have legal technical responsibilities. Furthermore, this situation is exarcebated by the fact that CETs technicians can be responsible to construction companies possessing a legal authorization for the execution of construction works that can go up to Class 4 permission (construction works with a value up to 1.328 million euros). And even if it is theoretically possible to admit that for the construction of new buildings this may not generate real problems the same cannot be said for conservation works, which possess a high complexity level. Since the majority of conservation works fall under the limit of class 4 it would be advisable if the Portuguese legal framework for the construction sector lower permission classes for building rehabilitation works. Even the few hundred construction enterprises that employ full time civil engineers do not take full advantage of that for conservation or rehabilitation purposes, because Portuguese civil engineering curricula is excessively structured around the construction of new buildings. Furthermore, this training has a majority of calculus based courses (structural, geotechnical, hydraulic, thermal, acoustic, etc.), and very few about building materials (one or two) so it is very difficult to ensure a minimum knowledge about conservation mortars [67]. This scenario does not allow great expectations for the sudden drop (and not expected) in the use of blended mortars in favor of the indiscriminate use of lime-pozzolan mortars, because this option could lead to an increase in execution based pathologies. Thus, and until substantial changes in training of technicians and

Table 6

Blended mortar fulfilling general mechanical and water performance requirements for rendering mortars of ancient buildings [58].

\begin{tabular}{|c|c|c|c|c|c|}
\hline Volume composition cement, lime, sand & Rt (MPa) & $\mathrm{Rc}(\mathrm{MPa})$ & $E(\mathrm{MPa})$ & $S_{d}(\mathrm{~m})$ & $C\left(\mathrm{~kg} / \mathrm{m}^{2} \min ^{0.5}\right)$ \\
\hline $1: 2: 9$ & 0.7 & $1.6-1.9$ & 4810 & 0.11 & $1.4-1.6$ \\
\hline
\end{tabular}

Rt - flexural strength; Rc - compressive strength; $E$ - Young modulus; $S_{d}$ - thickness of air layer with equivalent diffusion of water vapor; $C$ - capillary coefficient. 
workers operating in the conservation field, is achieved it can be assumed that there will be circumstances, such as the conservation works on buildings without historical value, for which the use of blended mortars can be an reprehensible option but still a lesser evil, provided they comply with minimum performance requirements in terms of mechanical behavior and water performance.

\section{Conclusions}

Lime based mortars cease to be used mostly because they were associated with exaggeratedly long hardening periods. This binder has been replaced by Portland cement that allows performing the same works with a minimum of time, but in the meantime it has proved to be a source of pathologies. Some elements of the scientific community have repeatedly recommended the use of limepozzolan mortars as the most suitable for conservation purposes, some authors refer to this as the only admissible solution, completely excluding the possibility of the use of Portland cement even in minimum percentages. This generated a Portland cement phobia. Nevertheless, other authors state the lime-cement mixes can be acceptable for repair of historic mortars especially in mortars historical buildings close to the sea environment. The use of commercial pre-pack mortars for conservation purposes are not without criticism because they are not cost-efficient, in many cases present an excessive mechanical performance and in most cases they are responsible for a high amount of soluble salts. These reasons favor the use of lime-cement mortars. As to lime-pozzolan mortars they are still under investigation, moreover its application requires the existence of skilled labor. The fact that the Portuguese construction market is composed mostly by workers with little or no training in terms of building materials and less about conservation materials, influences the importance of the right choice of conservation mortars and makes clear the importance of execution conditions in this type of work. Since Portuguese CET́s technicians with only 1 year post-secondary education in Polytechnic Institutions were allowed legal technical responsibilities worsens this problem. These conditions also favors the use of lime-cement mortars. It can then be assumed that is feasible to use blended lime-cement mortars for conservation purposes in buildings submitted to harsh environmental conditions and when skilled craftsmanship and good site practices cannot be met.

\section{References}

[1] The express magazine - a third part of Portuguese UNESCO architectural heritage at risk of collapse; 2009.

[2] Henriques F. The concept of acceptable technology in architectural conservation. ITAM-ARCCHIP-ARIADNE workshop 12, Czech Republic; 2003.

[3] Guerreiro C, Henriques FMA, Pinto AP. Comparative analysis of aerial lime hidraulic lime and blended binder for rendering mortars of ancient buildings. In: 2nd National congress for construction mortars. Lisbon: APFAC; 2007 [only in Portuguese].

[4] Freitas VP, Gonçalves PF. Specification and time required for the application of a lime-based render inside historic buildings. In: International conference HMC 08 - historical mortars conference: characterization, diagnosis, repair and compatibility. Lisbon: LNEC; 2008.

[5] Jornet A, Mosca C, Cavallo G, Corredig G. Comparison between traditional, lime based, and industrial, dry mortars. In: 2nd Historic mortars conference HMC2010 and RILEM TC 203-RHM final workshop, Prague, Czech Republic, 22-24 September; 2010. p. 631-41.

[6] Veiga R. Methodologies for characterization and repair of mortars of ancient buildings. In: International seminar historical constructions. Guimarães: Universidade do Minho; 2001.

[7] Veiga R. Interventions in ancient renders. Conservation actions, replacement or ... destruction. In: 2nd Meeting about pathology and rehabilitation. OPorto: PATORREB; 2006 [only in Portuguese].

[8] Veiga R. Conservation mortars. In: Proceedings of the 1st civil engineering meeting at the University of Aveiro. Evaluation and rehabilitation actions for buildings. COM 103. LNEC; 2003 [only in Portuguese].

[9] Veiga R, Carvalho F. Render mortars for ancient buildings. Requirements an characteristics to be fullfil. Build Collect 2002;2. LNEC [only in Portuguese]
[10] Teutonico JM, Naccaig I, Burns C, Ashurst J. The Smeaton project: factors affecting the properties of lime-based mortars. Bull Assoc Preserv Technol 1994;25:32-49.

[11] Margalha MG, Veiga MR, Brito J. The maturation time factor on the lime putty quality. In: 7th International brick masonry conference; 2006.

[12] Rodrigues PF, Henriques FMA, Rato VM. Current mortars: influence of aggregates and binder type. In: 2nd National congress for construction mortars. Lisbon: APFAC; 2007 [only in Portuguese].

[13] Cavaco LSR. Execution techniques for rendering mortars of ancient buildings. Master thesis, IST/UTL, Lisbon; 2005 [only in Portuguese].

[14] Penas F, Veiga R, Gomes A. Hydraulic lime mortars for use in ancient buildings: advantages and drawbacks. In: International conference HMC 08 historical mortars conference: characterization, diagnosis, repair and compatibility. Lisbon: LNEC; 2006.

[15] Roy DM, Langton C. Studies of ancient concretes as analogs of cementitious sealing materials for repository in Tuff. L A- 11527-MS. Los Alamos National Laboratory; 1989

[16] Malinowsky R. Prehistory of concrete. Concr Int 1991;13:62-8.

[17] Hazra PC, Krishnaswamy VS. Natural pozzolans in India, their utility distribution and petrography. Rec Geol Sur India 1987;87:675-706.

[18] Guleç A, Tulun A. Physico-chemical and petrographical studies of old mortars and plasters of Anatolia. Cem Concr Res 1997;27:227-34.

[19] Sbordoni-Mora L. Les matériaux des enduits traditionnels. In: Proceedings of the ICCROM symposium mortars, cements and grouts used in the conservation of historic buildings, Rome; 1981. p. 375-85.

[20] Degryse P, Elsen J, Waelkens M. Study of ancient mortars from Sagalassos (Turkey) in view of their conservation. Cem Concr Res 2002;21:1457-63.

[21] Bogue RH. The chemistry of Portland cement. New York: Reinhold Publication Corp.; 1955.

[22] Lea FM. The chemistry of cement. 3rd ed. London: Edward Arnold; 1970.

[23] Elsen J, Van Balen K, Mertens G. Hydraulicity in historic lime mortars: a review. In: Valek J, Groot C, Hughes J, editors. Proceedings of the 2nd conference and of the final workshop of RILEM TC 203 - RHM, Prague, Czech Republic, 22-24 September; 2010. p. 129-45.

[24] Rodrigues PF, Henriques FMA. The effects of hydraulic components on lime mortars. In: XXX IAHS world congress on housing, Coimbra, Portugal; 2002.

[25] Rodrigues PF, Henriques FMA. Current mortars in conservation: an overview. Int J Restorat 2004;10:622-92.

[26] Ambroise J, Murat M, Pera J. Hydration reaction and hardening of calcined clays and related minerals. Extension of the research and general conclusions. Cem Concr Res 1985;15:261-8.

[27] He Changling, Makovic Emil, Osbaeck Bjarne. Thermal stability and pozzolanic activity of raw and calcined illite. Appl Clay Sci 1995;9:337-54.

[28] He Changling, Osbaeck Byrne, Makovicky Emil. Pozzolanic reactions of six principal clay minerals: activation, reactivity assessments and technological effects. Cem Concr Res 1995;25:1691-702.

[29] He Changling, Makovic Emil, Osbaeck Bjarne. Thermal stability and pozzolanic activity of raw and calcined mixed-layer mica/smectite. Appl Clay Sci 2000;17:141-61.

[30] Fernandez R, Martirena F, Scrivener K. The origin of the pozzolanic activity of calcined clay minerals: a comparison between kaolinite, illite and montmorillonite. Cem Concr Res 2011;41:113-22.

[31] Amer A. Thermal analysis of hydrated fly ash-lime pastes. J Therm Anal Cal 1998;54:837-43.

[32] El-Shimy E, Abo-El-Enein S, El-Didamony H, Osman T. Physico-chemical and thermal characteristics of lime-silica fume pastes. J Therm Anal Cal 2000;60:549-56

[33] Giergiczny Z. Effect of some additives on the reactions in fly $\mathrm{ASH}-\mathrm{Ca}(\mathrm{OH})_{2}$ system. J Therm Anal Cal 2004;76:747-54.

[34] Gava G. Prudencio L. Pozzolanic activity tests as a measure of pozzolans performance. Part 1. Mag Concr Res 2007;59:729-34.

[35] Gava G, Prudencio L. Pozzolanic activity tests as a measure of pozzolans performance. Part 2. Mag Concr Res 2007;59:735-41.

[36] Velosa AL. Lime-pozzolans mortars for rendering of ancient masonry. PhD thesis, University of Aveiro, Portugal; 2006 [only in Portuguese].

[37] Almeida NG, Rodrigues PF, Pinto AP. Lime-rice husk ash based mortars for the conservation of the building heritage. In: 2nd National congress for construction mortars. Lisbon: APFAC; 2007 [only in Portuguese].

[38] Manita P, Triantafillou TC. Influence of the design materials on the mechanical and physical properties of repair mortars of historic buildings. Mater Struct 2011:44:1671-85.

[39] Veiga R, Fragata A, Velosa A, Magalhães A, Margalha G. Substitution mortars for application in historical buildings exposed to the sea environment. Analysis of the viability of several types of compositions. In: International conference HMC 08 - hystorical mortars conference: characterization, diagnosis, repair and compatibility. Lisbon: LNEC; 2008.

[40] Veiga R, Velosa A, Magalhães A. Experimental applications of mortars with pozzolanic additions: characterization and performance evaluation. Constr Build Mater 2009;23:318-27.

[41] Colantuono A, Dal Vecchio S, Marina O, Mascolo G, Vitale A. Cement-lime mortars joining porous stones of masonries able to stop the capillary rise of water. Cem Concr Res 1996;26:861-8.

[42] Mosquera M, Benitez D, Perry S. Pore structure in mortars applied on restoration: effect on properties relevant to decay of granite buildings. Cem Concr Res 2002;32:1883-8. 
[43] Mosquera M, Silva B, Priento B, Ruiz-Herrera E. Addition of cement to limebased mortars: effect on pore structure and vapor transport. Cem Concr Res 2006;36:1635-42.

[44] Arandigoyen M, Alvarez J. Blended pastes of cement and lime: pore structure and capillary porosity. Appl Surf Sci 2006;252:8077-85

[45] Arandigoyen M, Alvarez J. Pore structure and mechanical properties of cement-lime mortars. Cem Concr Res 2007;37:767-75.

[46] Sébaïbi Y, Dheilly R, Beaudoin B, Quéneudec M. The effect of various slaked limes on the microstructure of a lime-cement-sand mortar. Cem Concr Res 2006;36:971-8.

[47] Elpida-Chrissy A, Eleni-Eva T, Elizabeth V. Lime-pozzolan-cement compositions for the repair and strengthening of historic structures. In: International conference HMC 08 - historical mortars conference: characterization, diagnosis, repair and compatibility. Lisbon, Portugal: LNEC; 2008.

[48] Cizer O, Van Balen K, Van Gemert D, Elsen J. Blended lime-cement mortars for conservation purposes: microstructure and strength development. In: Structural analysis of historic construction: preserving safety and significance - proceedings of the 6th international conference on structural analysis of historic construction, SAHCO8 2, United Kingdom; 2008. p. 965-72

[49] Gonçalves T. Salt crystallization in plastered or rendered walls. PhD thesis, LNEC-IST/UTL, Lisbon, Portugal; 2007.

[50] Scherer GW. Crystallization in pores. Cem Concr Res 1999;29(8):1347-58.

[51] Flatt RJ. Salt damage in porous materials: how high supersaturations are generated. J Crys Growth 2002;242:435-54.

[52] Rato $\mathrm{V}$. The influence of morphologic microstructure on the performance of mortars. PhD thesis, UNL, Lisbon, Portugal; 2006. 316p.

[53] Groot C, Van Hees R, Wijffels T. Selection of plasters and renders for salt laden masonry substrates. Constr Build Mater 2009;23:1743-50.

[54] Martinez M, Carro G. Ancient building requirements and the evaluation of different lime- cement mortars compositions. In: 2nd National congress for construction mortars. Lisbon: APFAC; 2007.

[55] Faria J, Pacheco Torgal F, Jalali Said. Development of conservation mortars for ancient buildings. Parte 1 - workability and mechanical performance. J Civ Eng 2011;39:48-58. Portugal [only in Portuguese].
56] Faria J, Pacheco Torgal F, Jalali Said. Development of conservation mortars for ancient buildings. Parte 1 - capillary water absorption and water vapour permeability. J Civ Eng 2011;39:59-68,. Portugal [only in Portuguese].

[57] Sepulcre-Aguilar A, Hernández-Olivares F. Assessment of phase formation in lime-based mortars with added metakaolin, Portland cement and sepiolite, for grouting of historic masonry. Cem Concr Res 2010;40:66-76.

[58] Veiga R, Fragata A, Velosa A, Magalhães A, Margalha G. Substitution mortars for application in historical buildings exposed to the sea environment. Analysis of the viability of several types of compositions. In: International conference HMC 08 - hystorical mortars conference: characterization, diagnosis, repair and compatibility. Lisbon, Portugal: LNEC; 2008.

59] Veiga MR Conservation of historic renders and plasters: from lab to site. In: 2nd Historic mortars conference HMC2010 and RILEM TC 203-RHM final workshop, Prague, Czech Republic, 22-24 September; 2010. p. 1241-56.

[60] Veiga MR, Fragata A, Velosa AL, Magalhães AC, Margalha G. Lime-based mortars: viability for use as substitution renders in historical buildings. Int Architec Heritage 2010;4:177-95.

[61] Wijffels T, Groot C, Van Hees R. Performance of restoration plasters. In: 11th International brick/block conference. Shangai, China: Tongii University; 1997.

[62] Groot C, Van Hees R, Lubelli B, Wijffels T, Rooij M, Petkovik J. Aspects of salts and moisture transport in restoration plasters and renders. In: 6th International conference on materials science and restoration. Germany: University of Karlsrhue; 2003.

[63] Henriques F, Rato V, Rodrigues MP. Evolution of salt resistant mortars. In: 6th International symposium on the conservation of monuments in the mediterranean basin. Portugal: IST; 2004.

[64] Gomes F. Commercial pre-pack mortars for renders of ancient buildings. Master thesis, IST/UTL, Lisbon, Portugal; 2009 [only in Portuguese].

65] Rodrigues MP. Mortars for old masonries renders. The influence binders. PhD thesis, UNL, Lisbon, Portugal; 2004a. p. 523.

[66] Cóias V. Worker formation for rehabilitation purposes. The difference between failure and success. In: 2nd national congress for construction mortars. Lisbon, Portugal: APFAC; 2007 [only in Portuguese].

[67] Pacheco Torgal F, Jalali S. Some consideration about conservation mortars. Constr Mag 2009;32:35-9. Portugal [only in Portuguese]. 